\title{
SEDIMENTARY FACIES AND HYDROCARBON RESERVOIR POTENTIAL OF SAND FLAT IN THE UPPER PART OF TAPAK FORMATION IN BANYUMAS AREA, CENTRAL JAVA
}

\author{
FASIES SEDIMEN DAN POTENSI RESERVOIR HIDROKARBON SAND \\ FLAT FORMASI TAPAK BAGIAN ATAS DI DAERAH BANYUMAS, JAWA \\ TENGAH
}

\section{Yan Rizal', Wahyu Dwijo Santoso1, Alfend Rudyawan', Ricky Adrian Tampubolon', Affan Arif Nurfahan ${ }^{3}$}

${ }^{1}$ Geological Department, Institut Teknologi Bandung, Jln. Genesha 10 Bandung 40132, Indonesia

${ }^{2}$ Lemigas, Jalan Ciledug Raya, Kav. 109, Cipulir, Kabayoran Baru, Jakarta Selatan 12230

${ }^{3}$ Sekolah Tinggi Teknologi Mineral Indonesia, Jalan Gatot Subroto, Bandung

\begin{abstract}
The upper part of Tapak Formation in Kali Cimande consists of alternating sandstones, siltstone and mudstone. The alternating sequence showed a fining and thinning upward bedding pattern. The facies association of the alternation built up by sand flat facies, which characterized by medium sandstone, moderate sorted, with cross-lamination sedimentary structures and mostly on the top of sandstone layer found a bioturbation trace fossils (Skolithos). Mixed flat facies, which is characterized by an alternation of thin layered sandstones with mudstone and siltstone, with lenticular, wavy, and flaser sedimentary structures, contained many forms of bioturbation, such Planolites, Thallasinoides, Lockeia, and Ophiomorpha. Mud flat facies association, is characterized by a repeated of claystone with thin sandstone
\end{abstract}

Naskah masuk : 15 Maret 2018

Naskah direvisi : 3 Oktober 2018

Naskah diterima : 9 November 2018

Yan Rizal

Geological Department, Institut Teknologi Bandung, Jln. Genesha 10 Bandung 40132, Indonesia Email : yan@gl.itb.ac.id intercalation, where the ratio of clay content more than $95 \%$ of the total layers, contained abundantly with trace fossil Lockeia. Upper Tapak Formation plays as moderate reservoir potential. The thick sandstone in sand flat facies with moderate to poorly sorted and moderate porosity is required to provide hydrocarbon flows in Banyumas Basin.

Keywords: Tapak Formation, facies association, sand flat, mixed flat, mud flat.

ABSTRAK Bagian atas Formasi Tapak di Kali Cimande terdiri dari perselingan batupasirbatulanau dan mudstone. Sekuen perselingan menunjukkan pola perlapisan menghalus dan menipis ke atas. Asosiasi fasies tersebut terdiri dari fasies sand flat, yang dicirikan oleh batu pasir sedang, pemilahan sedang, struktur sedimen silang-siur serta fosil jejak bioturbasi (Skolithos) pada bagian puncak kebanyakan lapisan batu pasir. Fasies mixed flat, dicirikan oleh perselingan batupasir berlapis tipis dengan mudstone dan batulanau, serta struktur sedimen lentikular, perlapisan bergelombang, dan flaser, mengandung banyak bioturbasi, seperti Planolites, Thallasinoides, Lockeia, serta Ophiomorpha. Asosiasi Fasies sand flat, dicirikan oleh perulangan batulempung dengan sisipan batupasir tipis, dengan kandungan lempung lebih dari 95\% total lapisan, serta fosil jejak Lockeia yang melimpah. Formasi Tapak Atas berperan sebagai reservoir potensial sedang. Bagian batupasir tebal di fasies sand flat dengan 
pemilahan sedang hingga buruk dan porositas sedang diperlukan untuk menyediakan aliran hidrokarbon di Cekungan Banyumas.

Kata Kunci: Tapak Formation, facies association, sand flat, mixed flat, mud flat.

\section{INTRODUCTION}

Several hydrocarbon seepages were found along NW - SE Cipari Anticline (Lunt el al., 2008; Figure 1). Mulhadiyono (2006) reported that one of potential reservoir with some oil seepage was found at Tapak Formation. Oil seepage that penetrated Tapak Formation was observed in Bumiayu Area. KRG -1 well was drilled on 1992 by Pertamina with the target to penetrate Tapak Formation. However, KRG-1 well was stopped on 1851 meters with no hydrocarbon shows. This well just penetrated three meters of carbonate of Tapak Formation and 1800 meters of Halang
Formation. The failure of hydrocarbon discoveries caused that this area was marked as doubtful prospect.

The detail information and history of exploration in Tapak Formation is still not adequate. Several failured of hydrocarbon discoveries in Banyumas Basin while many hydrocarbon seepages were found in this formation shows depositional and play concept of Tapak Formation still interesting and challenging because BP Migas - LAPI ITB (2008) stated that the Banyumas Basin is classified as a basin with hydrocarbon discoveries. As starting point, the study of sedimentation process and depositional facies of Upper Tapak Formation was performed in Cimande River. This study tried to conduct the relationship between sedimentation facies and petroleum play of the sandstone of Upper Tapak Formation.

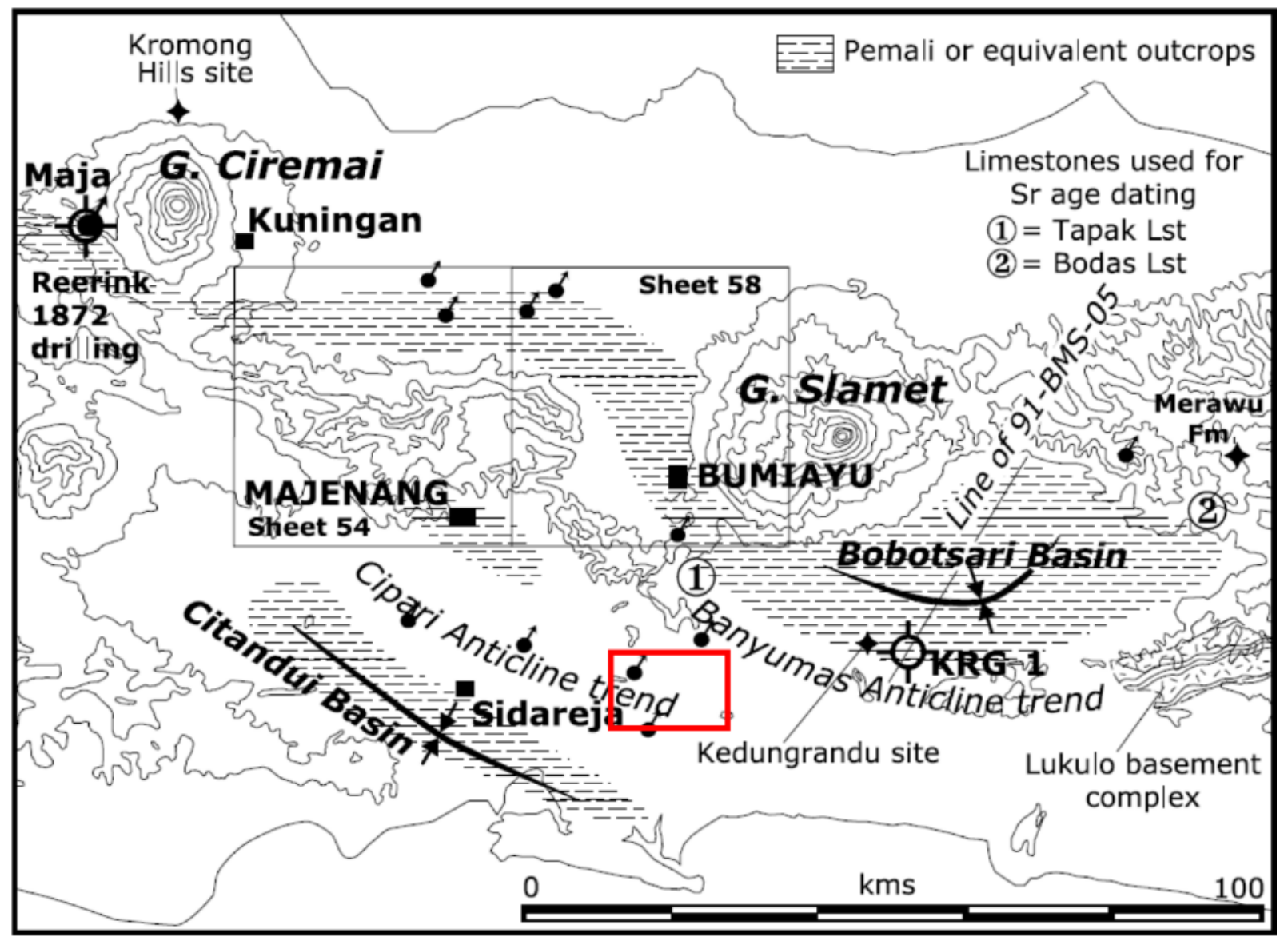

Figure 1 Several oil seepages in the Cipari Anticline. The research area was marked by red box (modified after Lunt et al., 2008). 


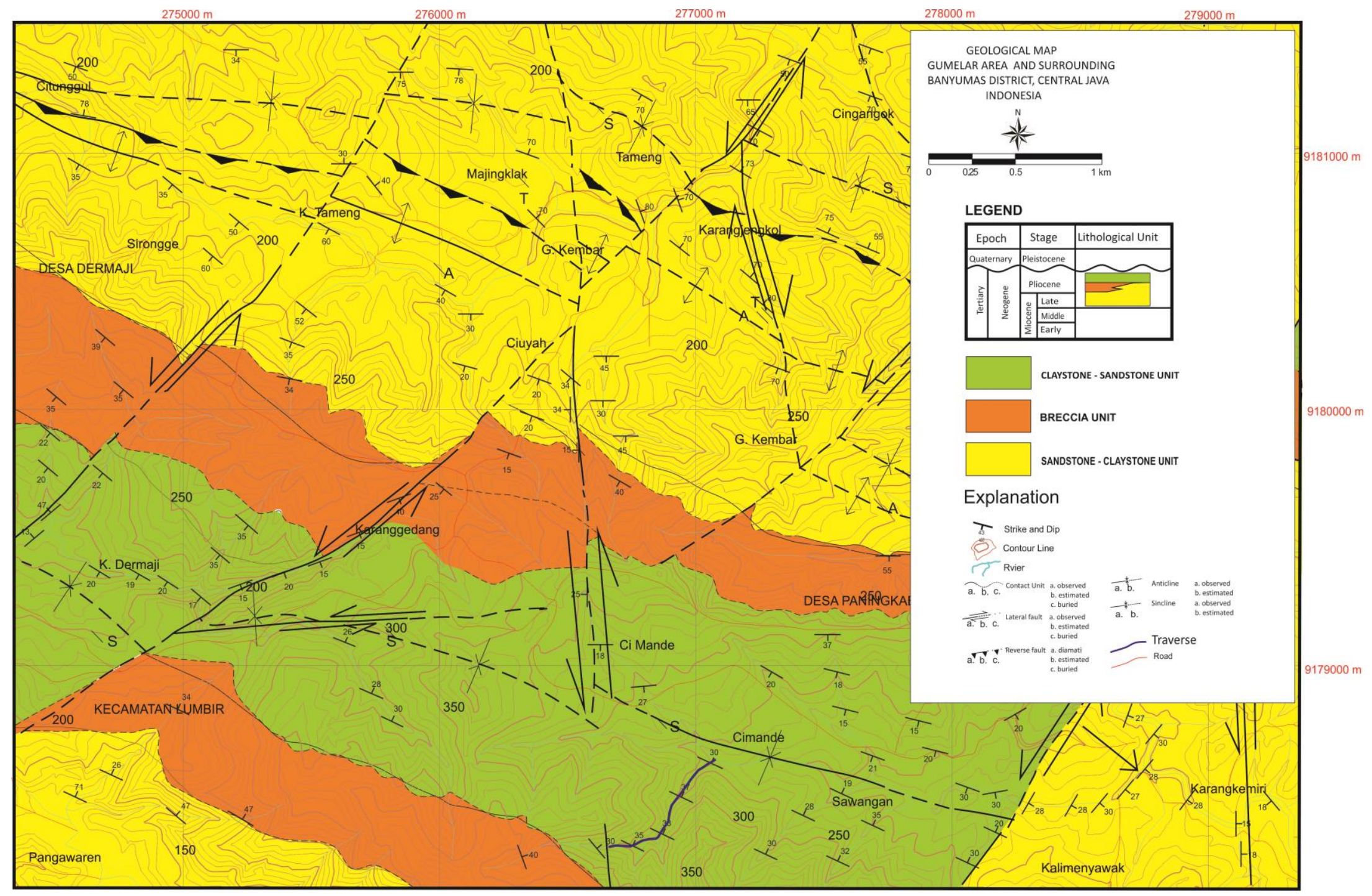

Figure 2. The research location in Banyumas Area and sketch of measuring section traverse (modified from Tampubolon 2014). 


\section{Supratidal}

- Above high - tide level - Multigenic sedimentary structures - Development of salt marshes - Presence of rooded muds

- High internal heterogeneity
Intertidal

Between high- and low-tide levels

Multigenic sedimentary structures

- Development of tidal flats and runoff chann

- Subdevided in mud, mixed, and sand flats

\section{Mixed flat}

Below low-tide level

Dominance of bedloas-deposition

generatedsedimentary structure

High - energy evironment

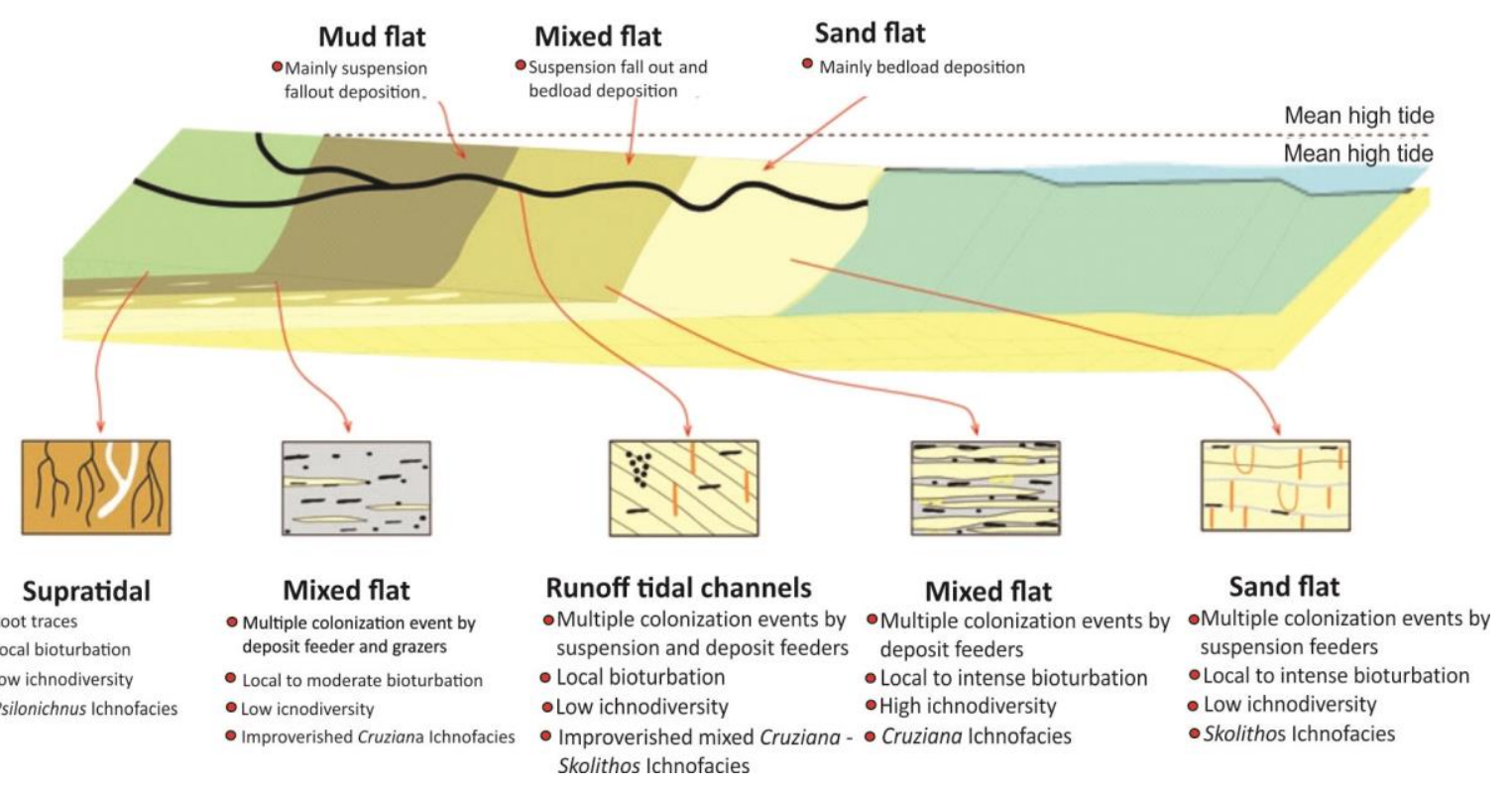

Figure 3a. Integrated sedimentological and ichnological model for intertidal to supratidal environments (Desjardin, 2012).

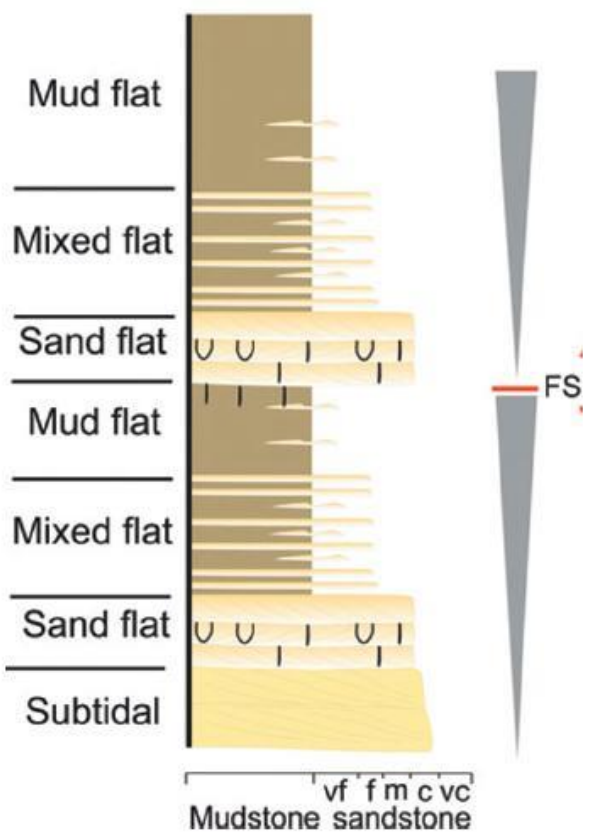

Figur $3 \mathrm{~b}$. Vertical succession of Tidal flat, which the shown a change of from mud flat to bioturbated sand flat as a border of flooding surface (Desjardins et al., 2012). 


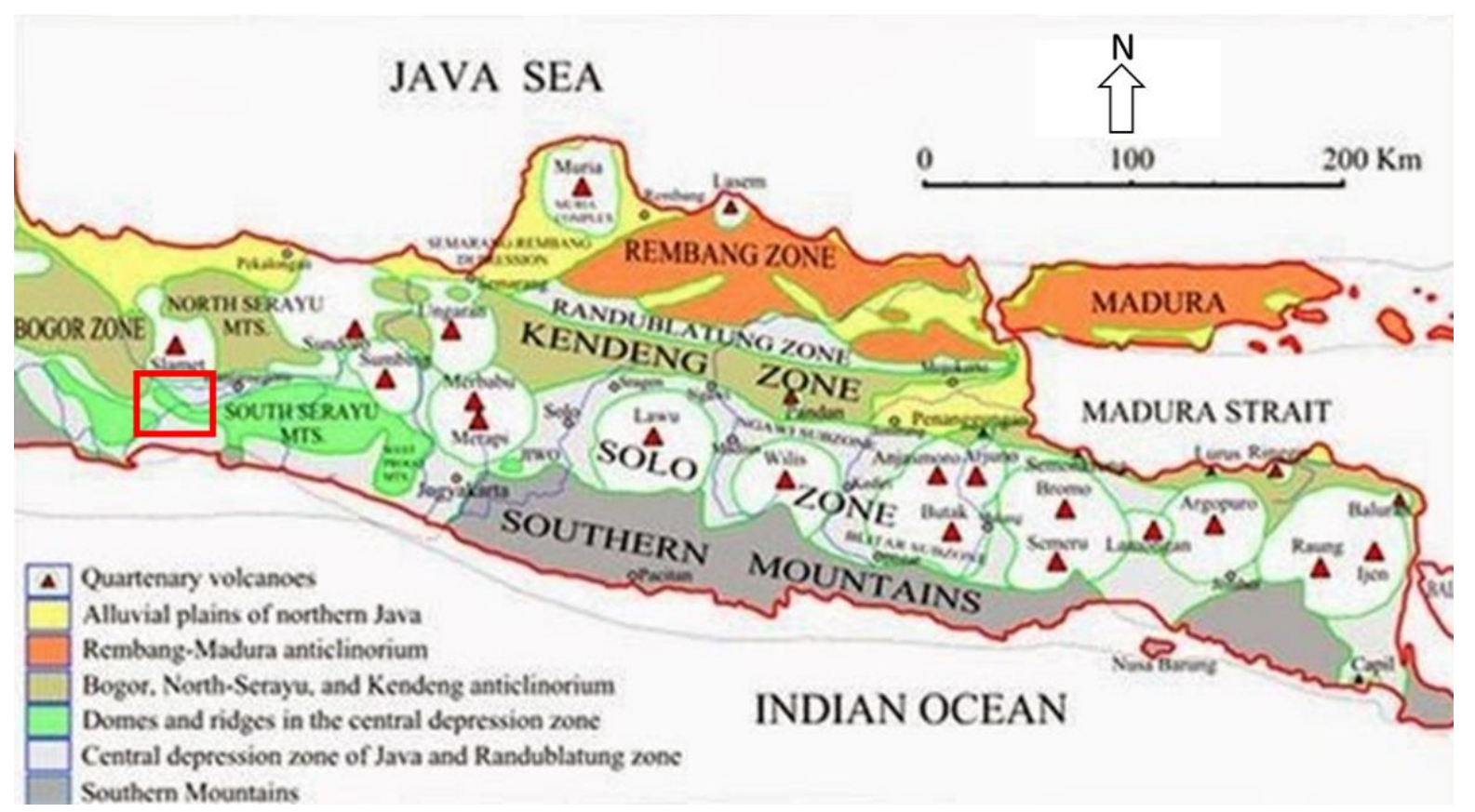

Figure 4. Physiography map of central Java (modified from Van Bemmelen, 1949). The research area is bordered by red box.

\section{METHODS}

The study is basically a field-work observation conducted in Cimande River, Banyumas Area (Figure 2). This location was selected from many location in the study area and which is estimated to represent the vertical sucession of the Upper Tapak Formation found in the study area because the continous and thick sedimentary rock was exposed in this river. 90 meters continuous outcrop was measured and described the detail of sediment layers as a representation of rock unit of Upper Tapak formation in the study area (Figure 2 ). The result of continuous outcrop analysis was classified and identified into facies associations of the shallow marine deposits models of Desjardin et al (2012) (Figure 3a and 3b).

According to physiography map of Central Java (van Bemmelen, 1949), the study area is located in the South Serayu Mountain Zone (Figure 4) consists of steep hills that extends to the northwest-southeast direction. This zone is the southern part of Banyumas Basin.

Tectonically, this area confirmed as the product Eurasia Plate and Indo-Australia Plate interaction. This interaction resulted intermediate accreted terrain as the basement of Banyumas Basin. Active tectonic during Miocene created the accumulation of Pemali Formation as syn rift deposit on Early Miocene (Lunt et al., 2008). The tectonic period became slowdown during Middle - Late Miocene period. Re- activation of tectonic was occupied during Plio - Pleistocene period that marked by NW - SE anticline that followed by reverse fault.

Kastowo and Suwarna (1996) devided the stratigraphy of South Serayu Montain into seven formation (Figure 4). Tapak Formation was deposited on Early Pliocene and divided into two members, namely Lower Tapak and Upper Tapak Member (Djuri et al., 1996).

Lower Tapak was characterized by interbedded coarse sandstone and marl, greenish sand, conglomerate and breccia in many spots. Upper Tapak was marked by calcareous sandstone, limestone, and marl with mollusc fragments. The thickness of the Tapak formation is about $500 \mathrm{~m}$ which deposited in shallow marine environments (Kertanegara et al., 1987) and locally found reef limestone (Marks, 1957).

\section{RESULTS AND DISCUSSION}

Generally, the Upper Tapak Formation in the Cimande River section consists of alternation of mudstone and sandstone with calcarenite intercalation with 90 meters thickness. Sandstone 


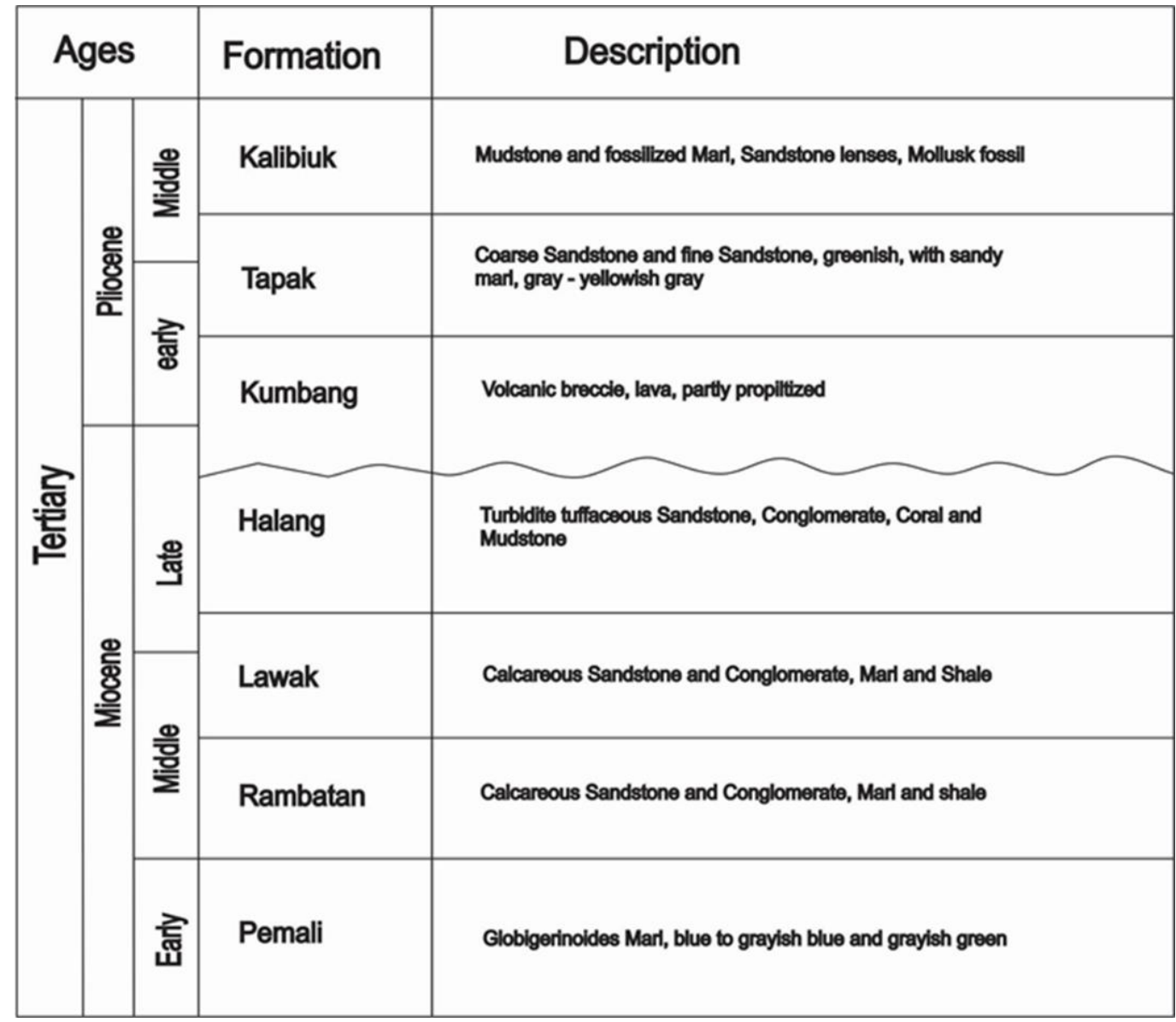

Figure 5 Regional Stratigraphy of South Serayu (Kastowo and Suwarna, 1996).

has description light gray color, fine to medium grain size, moderate to poorly sorted, fair porosity. The compositions are dominated by fossil fragments, Plagioclase and quartz, cemented by carbonate material. The thickness of the layer of sandstone varies from $10 \mathrm{~cm}$ to $120 \mathrm{~cm}$. Mudstone has description gray to greenish gray, calcareous, contain foraminifera and shell fragments. Calcarenite limestone has description yellowish gray, fine grain size, well sorted, compact and hard, generally present as thin bedding. The interbedded of sandstone shows fining and thinning upwards succession with lenticular, wavy, and flaser sedimentary structure (Figure 6, 7).

The abundant of trace fossils association is interpreted that the Upper Tapak Formations in the study area was deposited in the tidal flats which belong to the intertidal zone. Based on lithological characteristics and patterns of succession and trace fossil content, the depositional environment of intertidal zone can be divided into sand flat facies, mixed flat facies, and mud flat facies.

\section{Sand Flat Facies associations}

This facies association is composed of sandstone with mudstone intercalation. Sandstone has medium grain size, moderate sorted, crosslamination and Skolithos trace fossils at the upper part (Figure 7). Base on microscopic analysis the sandstone is Feldpathic Wacke, moderate to poorly sorted, open package (point / concavo / sutured contact), grains $(50 \%)$ consist of plagioclase, quartz, mafic minerals, opaque minerals, rock fragments and foraminifera fossil fragments of benthic and planktonic, rounded angular shape, matrix $(20-30 \%)$, cement $(10-$ $15 \%)$, porosity $(10-15 \%)$ in the form of moldic, intergranular, intergranular (Figure 8,9).

The thickness of this facies succession is around 10 meters. The vertical succession of this facies can be seen in the Figure 10. 


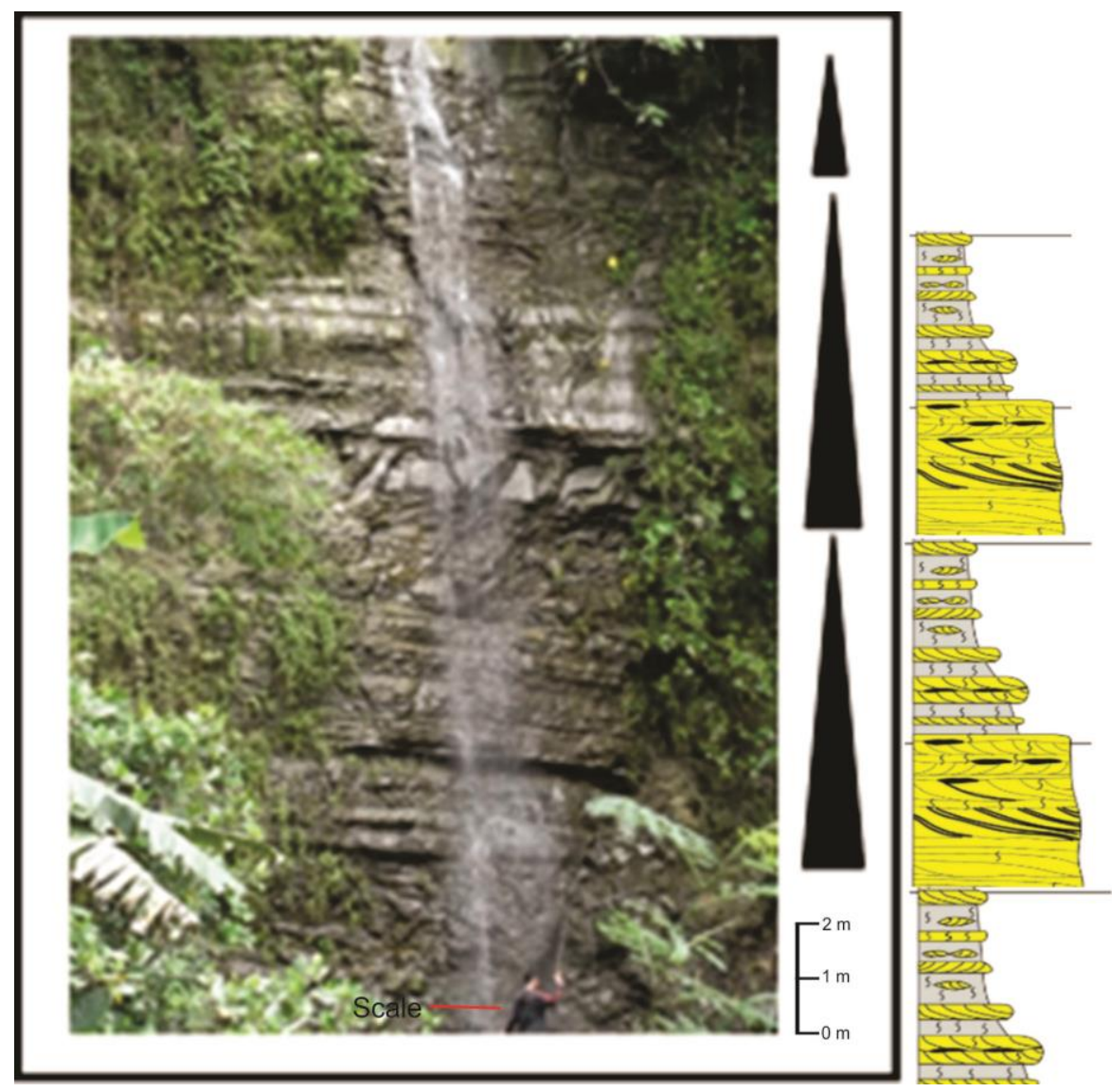

Figure 6 Outcrop of mudstone-sandstone which show a pattern of fining and thinning upward.

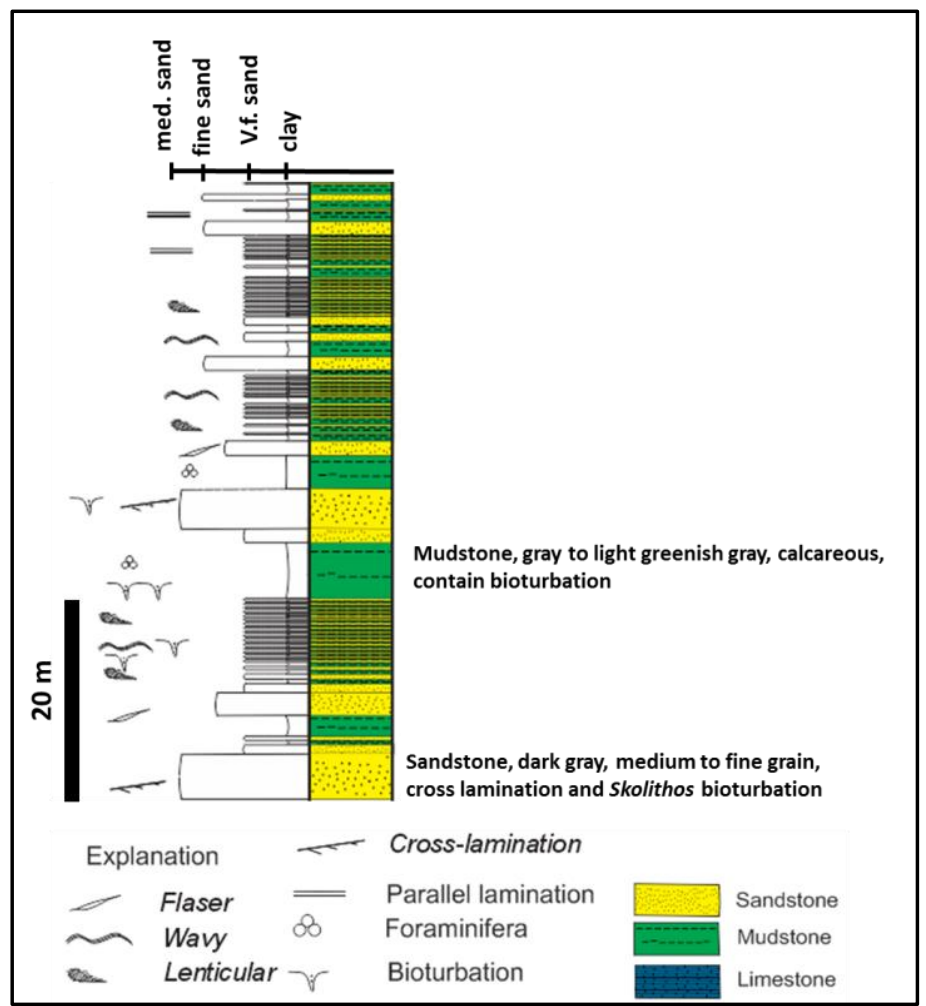

Figure 7 Profile of interbedded of mudstone - sandstone in Kali Cimande. 


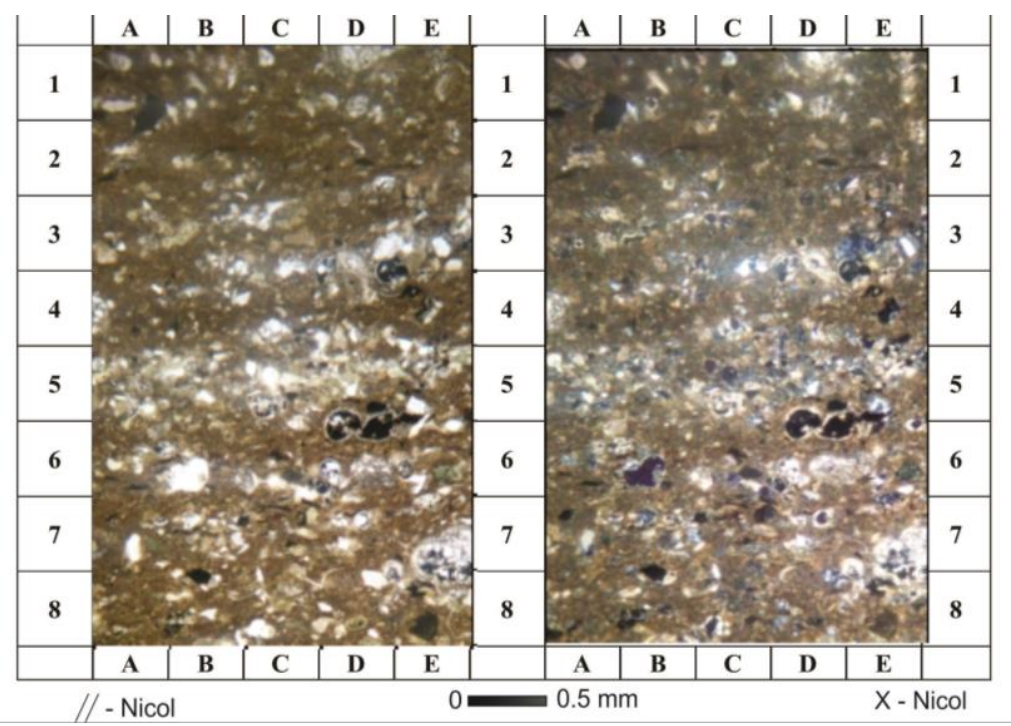

Figure 8 Thin Section on the sandstone sample from the upper layer in Figure 11.

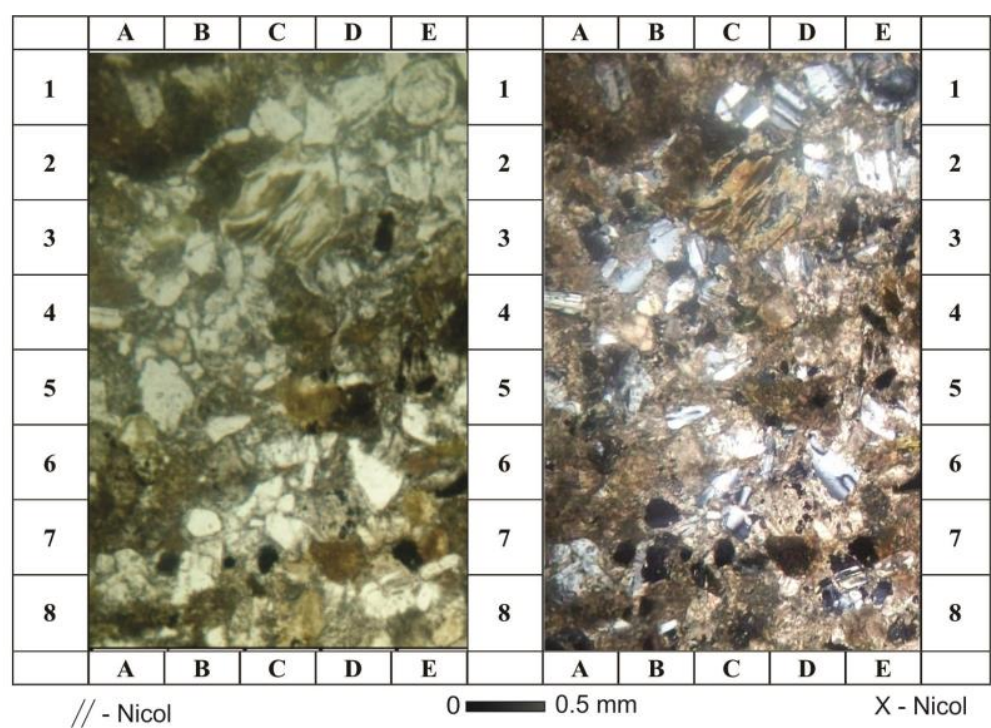

Figure 9 Thin Section on the sandstone sample from the lower layer in Figure 11.

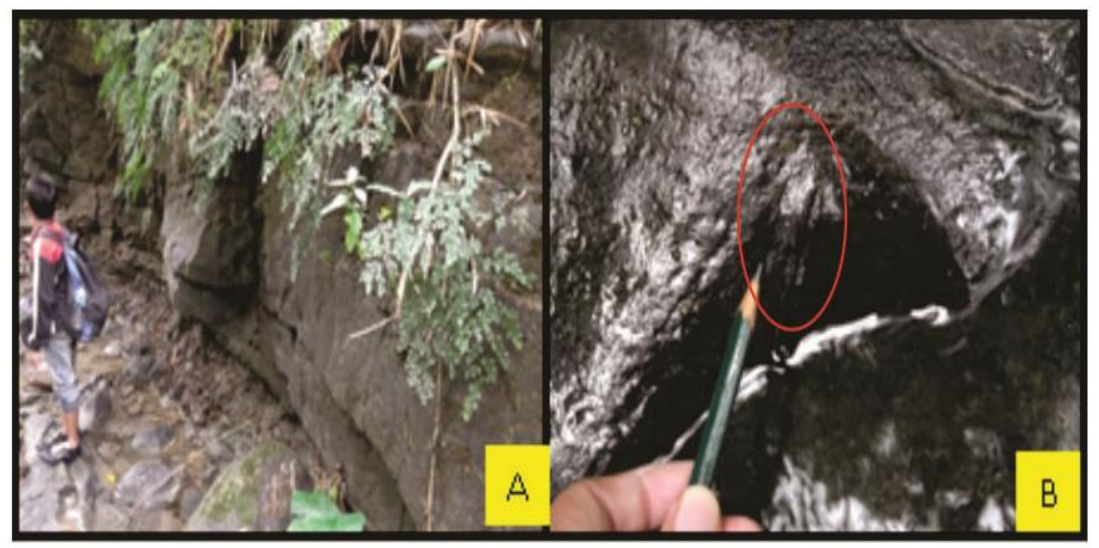

Figure 10 (A) Outcrop sand flat facies associations and (B) Skolithos bioturbation in this facies. 


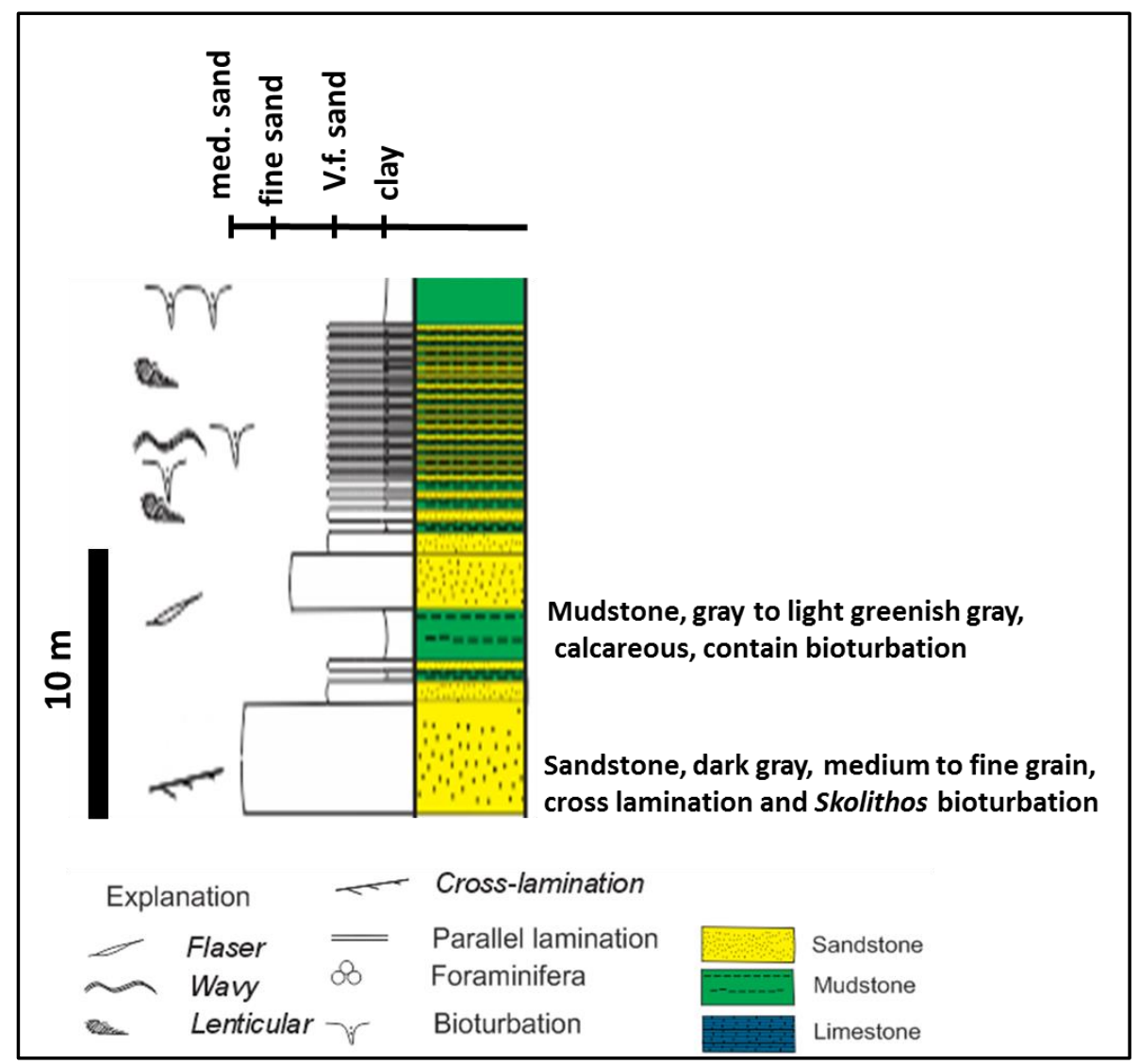

Figure 11 Vertical succession of sand flat facies shows fining upward trend.

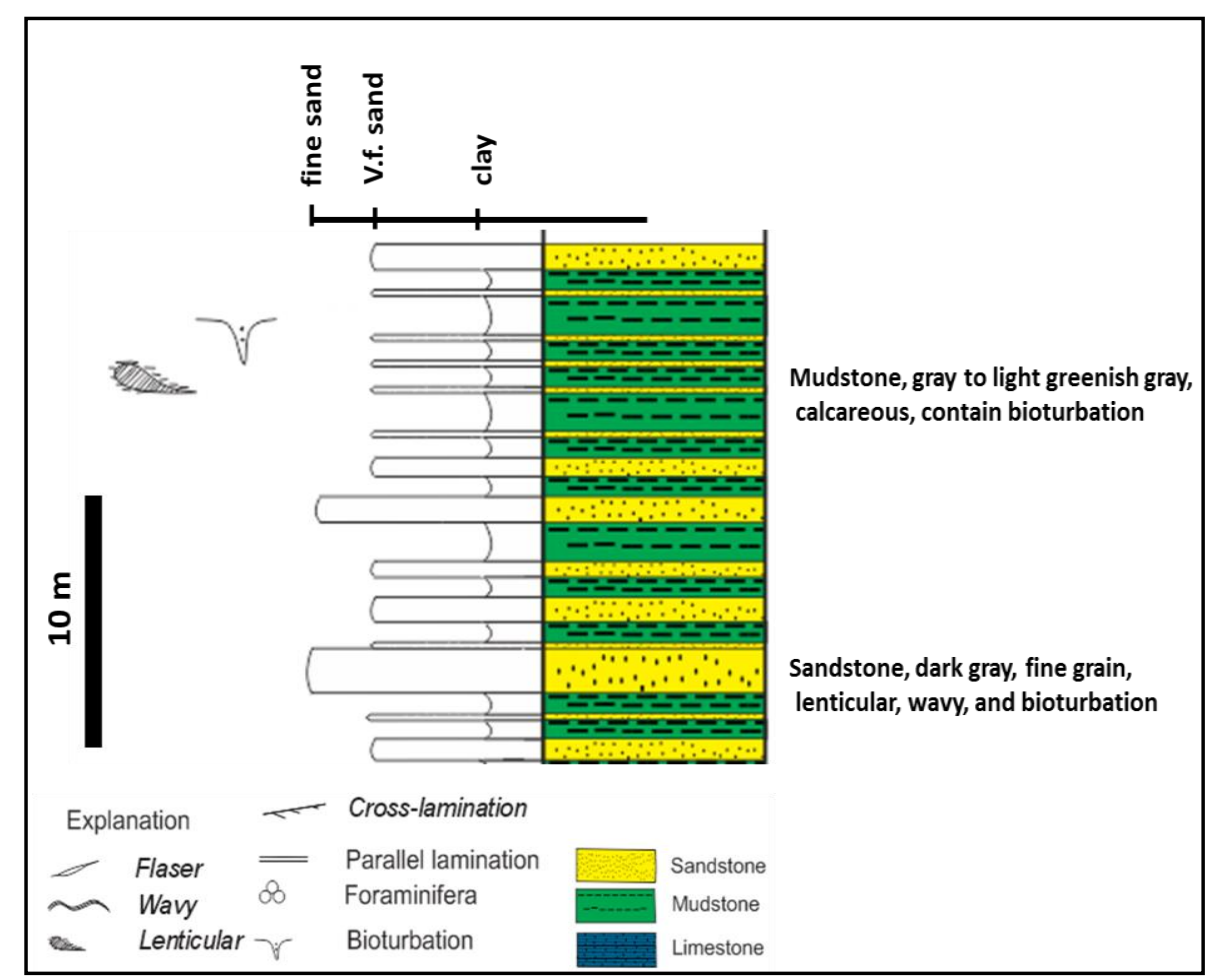

Figure 12 Vertical succession of mix flat facies consists of a series of alternating mudstone - thin layered fine sandstone. 


\section{Mixed Flat facies associations}

This facies association is characterized by interbedded of thin layered of fine sandstone and mudstone (Figure 12). The thickness of sandstone varies from $1 \mathrm{~cm}$ to $10 \mathrm{~cm}$, rich with lenticular, wavy, and flaser sedimentary structures (Figure 13). The alternation contained a bioturbation in form of Planolites, Thallasinoides, Lockeia, and Ophiomorpha (Figure 14).
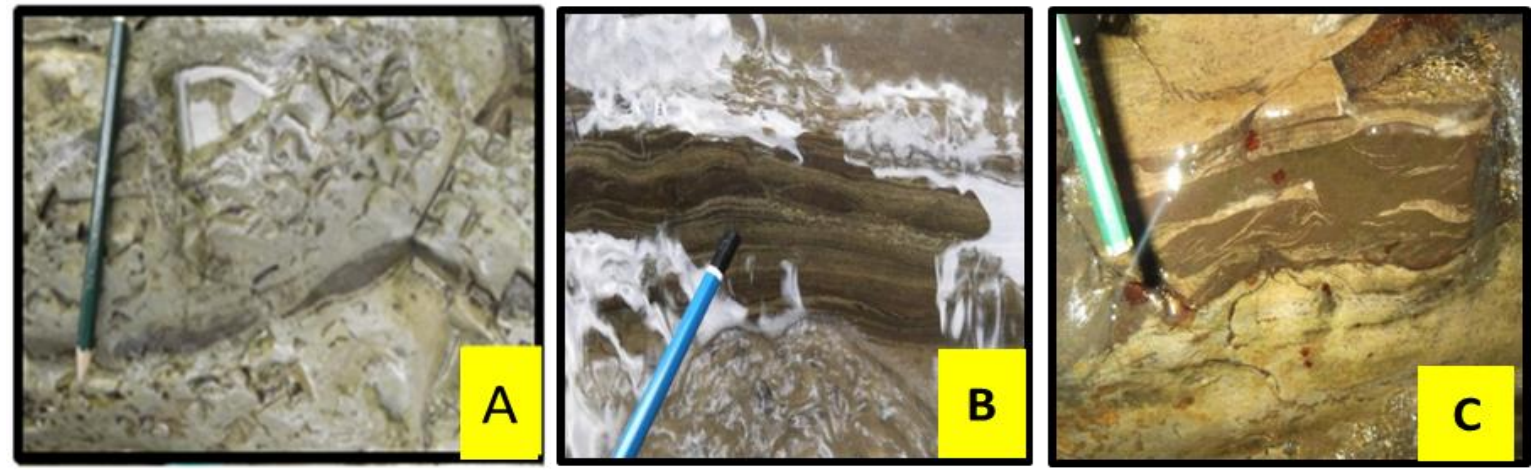

Figure 13. Alternation of thin layered of sandstone, mudstone with lenticular form (A), wavy lamination (B), and flaser (C) sedimentary structure.

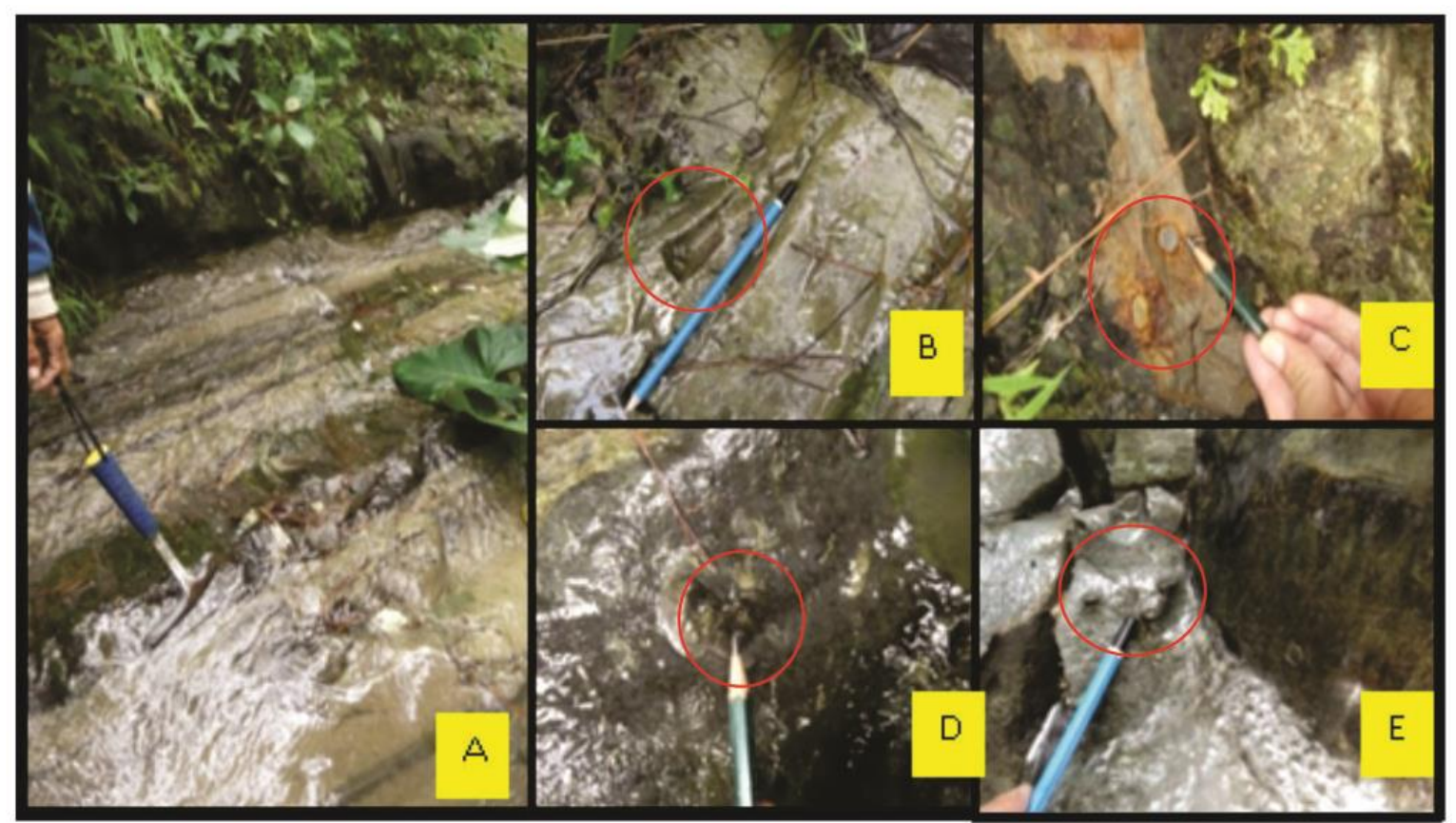

Figure 14. (A) Outcrops of sandstones and mudstone alternation (mixed flat facies associations) with bioturbation:

(B). Planolites, (C).Ophiomorpha, (D) Zoophycos, and (E) Lockeia. 


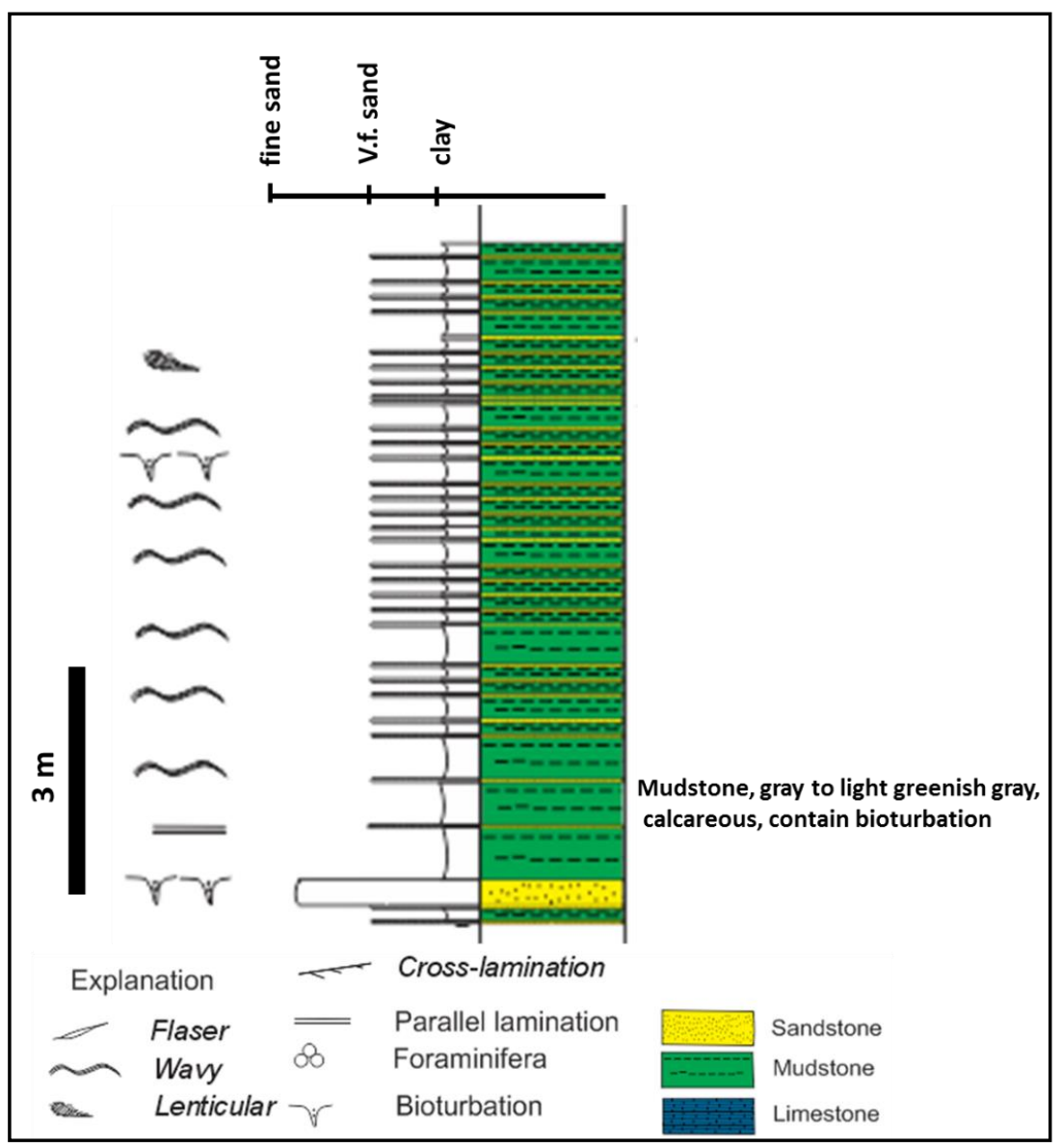

Figure 15. Vertical Succession of mud flat facies.

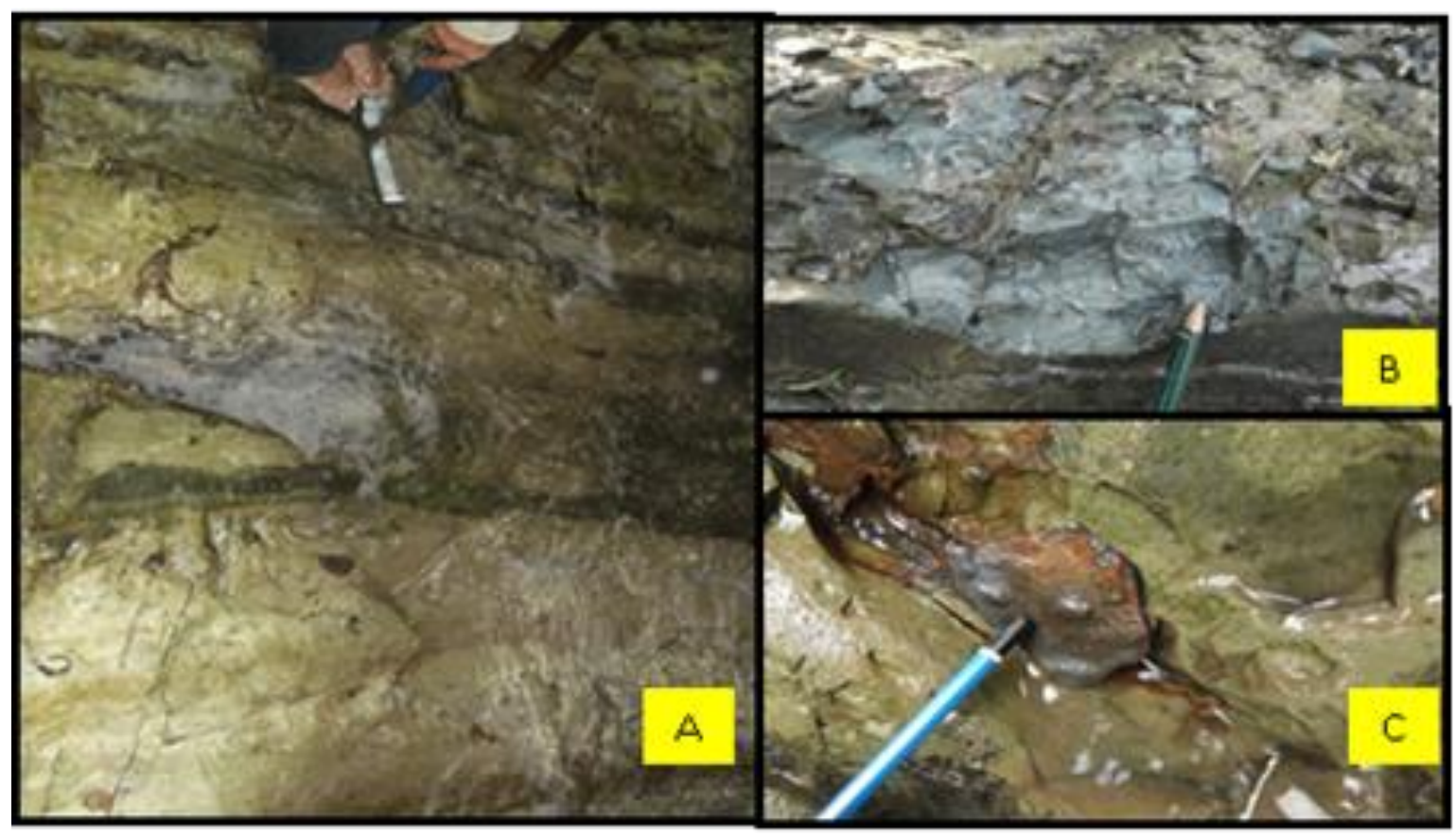

Figure 16. Outcrops of mud flat facies associations dominated by mudstone (A). Greenish gray mudstone rich with foraminifera fossils (B) and bioturbation Lockeia abundant in mudstone (C). 


\section{Petroleum System Potential}

Petroleum potential evaluation of Upper Tapak Formation requires many integrated studies. Structural and stratigraphic correlation analysis must be performed to get the better understanding for the further petroleum play. This study will provide the preliminary evaluation of Upper Tapak Formation. A detail analysis supported by laboratory analysis must be carried out to know the physical and chemistry characteristic of Upper Tapak Formation.

The source rock of Banyumas Basin refers to Halang Formation and Pemali Formation. Noeradi et al. (2006) analyzed Halang and Pemali Formation samples that revealed $0.5 \%$ TOC with hydrogen index (HI) below 200. The TOC value represents Halang and Pemali Formation is classified into good source rock. However, no Samples of Tapak Formation was recorded that was performed for geochemistry analysis.

Based on the porosity of sandstone of sandflat facies $(10-15 \%)$, that can be categorized in to moderate porosity (Ehrenberg and Nadeau, 2005), the Upper Tapak Formation may plays as moderate reservoir potential. The thick sandstone in sand flat facies with moderate to poorly sorted and moderate porosity is required to provide hydrocarbon flows in Banyumas Basin. This fact is proven by oil seepages that penetrate the Upper Tapak Formation along Cipari Anticline. The detail routine and special core analysis must be carried out to support the detail physical parameter of Tapak Formation. Moreover, the Upper Tapak Formation can be act as regional seal. Thick clay deposits in mud flat facies are widely distributed along South Serayu Mountain and Banyumas Basin. The thick clay deposit can resist the hydrocarbon flows from sand flat facies and keep the hydrocarbon preserve along anticline axis in Banyumas Basin, such as Cipari Anticline and Banyumas Anticline.

\section{CONCLUSIONS}

Upper Tapak formation at kali Cimande area consists of a repeating succession of alternation of sandstone with siltstone and mudstone with layering pattern of fining and thinning upward. Facies associations of the sandstone with siltstone and claystone alternation consisted of:

- Sand flat facies associations are characterized by layers of medium sandstone, moderate to poorly sorted, moderate porosity, with crosslamination sedimentary structures and at the top of many layers there are fossil trail of bioturbation types Skolithos

- Association of Mixed Flat facies characterized by thin layered of sandstones, mudstone and siltstone, rich with lenticular, wavy, and flaser sedimentary structures, containing trail fossil of bioturbation types Planolites, Thallasinoides, Lockeia, and Ophiomorpha

- Mud Flat facies association is characterized by repeating of thin layered mudstone with sandstone intercalation, characterized by mudstone content ratio> $95 \%$ of the total layers. In the mudstone often found fossilized trail of bioturbation types abundantly Lockeia.

- Upper Tapak Formation plays as reservoir potential. The thick sandstone in sand flat facies with moderate to poorly sorted and moderate porosity is required to provide hydrocarbon flows in Banyumas Basin.

\section{REFERENCES}

BP Migas and LAPI ITB, 2008. Indonesian Tertiary Basin. 2, 1-15.

Desjardins, P., L. A. Buatois, and M. G. Mangano., 2012. Tidal Flats and Subtidal Sand Bodies Development in Sedimentology vol.64, Elsevier.

Djuri, M., Samodra, H., Amin T. C., and Gafoer, S., 1996. Geological Map Sheet of Purwokerto-Tegal, scale 1:100.000, Geology Research and Development Center, Bandung.

Kastowo and Suwarna, N., 1996. Geology Map of Majenang Sheet, Scale of 1: 100.000, Geology Research and Development Center, Bandung.

Kertanegara, L., Uneputty,H., and Asikin, S., 1987. Stratigraphy and Tectonic position of North Central Java Basin during Tertiary Period, $16^{\text {th }}$ Proceeding of Indonesian Geologist Conference, Bandung.

Lunt, P., Burgon, G., and Baky, A., 2008. The Pemali Formation of Central Java and equivalents: Indicators of sedimentation 
on an active plate margin, Journal of Asian Earth Science, vol. 34, 100 - 113.

Marks, P., 1957. Stratigraphic Lexicon of Indonesia, Publikasi Keilmuan Seri Geologi No.31, Djawatan Geologi Bandung.

Mulhadiyono, A. A., 2006. Petroleum possibilities of the Banyumas Area, Proceeding of Indonesia Petroleum Association, p. 121-129.

Noeradi, D., Subroto E. A., Wahono H. E., Hermanto E., and Zaim Y., 2006. Basin evolution and hydrocarbon potential of Majalengka-Bumiayu Transpression Basin, Java Island, Indonesia, AAPG 2006 International Conference and Exhibition, Perth, Australia, 2006. Tampubolon, R., 2014.

Nugroho, D, 1998. Analisis Distribusi Elemen Arsitektur pada Formasi Bayah, Tesis Magister, ITB, Bandung.
Reading, H. G., 2001. Clastic Facies Models, A Personal Perspective, Bulletin of the Geological Society of Denmark vol. 48.

Tampubolon, R., 2014. Geology and Facies Study of Halang and Tapak Formation in Gumilar Area, Banyumas, Central Java Province, Bachelor Thesis, Institut Teknologi Bandung.

Van Bemmelen, R. W., 1949. The Geology of Indonesia, Martinus Nijhof, The Hague, The Netherland.

Walker, R. G., and James N. P, 1992. Facies Models, Response to Sea Level Change, Geological Association of Canada.

Walker, R. A., 1984. Facies Models, Geological Association of Canada Publication, Bussiness and Economic Service, Canada. 